\title{
Layered cryogels laden with Brazilian honey intended for wound care
}

\author{
Gabriela de Souza dos Santos ${ }^{1}$ (D), Natália Rodrigues Rojas dos Santos ${ }^{1}$ (D), \\ Ingrid Cristina Soares Pereira' ${ }^{1}$ (D), Antonio José de Andrade Júnior ${ }^{1}$ (D), Edla Maria Bezerra Lima² (D), \\ Adriana Paula Minguita² (D), Luiz Henrique Guerreiro Rosado ${ }^{3}$ (D), Ana Paula Duarte Moreira ${ }^{4}$ (D), \\ Antonieta Middea $^{5}$ (D), Edlene Ribeiro Prudencio ${ }^{6}$ (D), Rosa Helena Luchese ${ }^{6}$ (D) and Renata Nunes Oliveira ${ }^{3 *}$ \\ ${ }^{1}$ Departamento de Engenharia Química, Instituto de Tecnologia, Universidade Federal Rural do Rio de \\ Janeiro - UFRRJ, Seropédica, RJ, Brasil

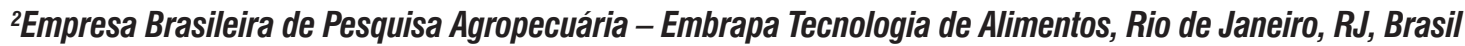 \\ ${ }^{3}$ Programa de Pós-graduação em Engenharia Química, Instituto de Tecnologia, Universidade Federal \\ Rural do Rio de Janeiro - UFRRJ, Seropédica, RJ, Brasil \\ ${ }^{4}$ Programa de Engenharia de Materiais e Metalurgia, Universidade Federal do Rio de Janeiro - UFRJ, Rio \\ de Janeiro, RJ, Brasil \\ ${ }^{5}$ Centro de Tecnologia Mineral, Universidade Federal do Rio de Janeiro - UFRJ, Rio de Janeiro, RJ, Brasil \\ ${ }^{6}$ Departamento de Engenharia de Alimentos, Instituto de Tecnologia, Universidade Federal Rural do Rio \\ de Janeiro - UFRRJ, Seropédica, RJ, Brasil \\ *renatanunes.ufrrj@gmail.com
}

\begin{abstract}
PVA cryogels are well established as candidate biomaterials for wound healing applications but are not themselves biodegradable or antimicrobial. Blending PVA with NaCMC (CMC) or gelatin (G) can increase the gel's ability to swell and would introduce a degree of biodegradability. The incorporation of appropriate amounts of a natural antimicrobial/healing agents, such as honey $(\mathrm{H})$, would contribute to the gels properties. The present work addresses the development and characterization of layered gels (PVA-H, PVA-CMC-H and PVA-G-H, with empty PVA, PVACMC, PVA-G gels presented as controls). The gels were characterized by FTIR, DSC, in vitro analysis of swelling and microbiological (S. aureus) effects. Addition of gelatin, NaCMC and honey to PVA diminished the PVA chains' ability to pack into crystallites. Samples containing honey swelled less and presented higher weight loss/biodegradability than samples without honey. Only the honey-laden PVA-CMC and PVA-G presented activity against S. aureus.
\end{abstract}

Keywords: layered hydrogel, PVA, NaCMC, gelatin, honey.

How to cite: Santos, G. S., Santos, N. R. R., Pereira, I. C. S., Andrade Júnior, A. J., Lima, E. M. B., Minguita, A. P., Rosado, L. H. G., Moreira, A. P. D., Middea, A., Prudencio, E. R., Luchese, R. H., \& Oliveira, R. N. (2020). Layered cryogels laden with Brazilian honey intended for wound care. Polimeros: Ciência e Tenologia, 30(3), e2020031. https:// doi.org/10.1590/0104-1428.06820

\section{Introduction}

Infection associated with wounds to the skin affect 14 million people per year in the USA. Such infections are characterized by colonization by gram-positive bacteria such as $\mathrm{S}$. aureus in the early stages of healing, which are later replaced by gram-negative organisms ${ }^{[1]}$. Requirements for successful healing include a mechanically stable and moist environment, a capacity for absorbing wound exudate, and antimicrobial properties which act against the development of infection.

Hydrogels have been manufactured in layers to mimic the layers and function of the skin. For example, chitosang-poly(ethylene glycol) hydrogel reinforced with chitosanalginate were designed to mimic the micro-environment relevant to skin tissue engineering ${ }^{[2]}$. A hydrogel composed of layers of alginate/chitosan/poly(-glutamic acid) increased wound epithelialization and collagen regeneration ${ }^{[3]}$. Layered hydrogels based on PVA (polyvinyl alcohol) have also been developed: 2-layered skin equivalent PVA or PVAcellulose fibre blocks were prepared by freeze-thawing and presented roughness and elasticity similar to human $\operatorname{skin}^{[4]}$. A PAA layer has been added to a PVA layer, with the PAA solution poured on the top of PVA swollen layer, where the chains of both polymers would entangle and form hydrogen bonding at the interface. The presence of PAA led to increased swelling, adhesion and biocompatibility while the presence of PVA underpinned the mechanical properties of the gel ${ }^{[5]}$. Hydrogels are potential materials for burn dressings. 
PVA is a hydrophilic biocompatible polymer used to manufacture hydrogels. PVA hydrogels are capable of presenting physical properties similar to human tissue, such as elasticity ${ }^{[6]}$. Hydrogels can be based on chemical crosslinking or physical crosslinking, where chemical crosslinking is based on the use of crosslinking agents, such as glutaraldehyde, or based on the use of radiation ${ }^{[7,8]}$. Physically crosslinked PVA hydrogels can be prepared by freezing and then thawing an aqueous solution of PVA. PVA chains entangle when in solution. When frozen, ice crystals are formed. By phase separation (ice/PVA), PVA chains are pushed together forming crystallites, which are responsible for the high mechanical properties of these gels. These gels have tissue-like elasticity, toughness and are non-toxic ${ }^{[9]}$. Blended PVA gels incorporating several additives, such as L. bulgaricus extract ${ }^{[10]}$ and neomycin sulfate ${ }^{[11]}$, have been studied in the literature with respect to antibacterial and healing properties.

Sodium carboxymethyl cellulose $(\mathrm{NaCMC})$ is a hydrophilic polymer, a polyelectrolyte, derived from cellulose. The charges of this polyelectrolyte elongate the polymer chains, increasing the water uptake capability of the network, with counterions favouring water entrance ${ }^{[12]}$. $\mathrm{NaCMC}$ is able to form hydrogels by blending it with hydroxyethyl cellulose and chemically crosslinking with divynilsulphone ${ }^{[12]}$; $\mathrm{NaCMC}$ can be combined with protein sericin, crosslinked by freeze-thawing, with glutaraldehyde and $\mathrm{AlCl}_{3}$ to produce hydrogels for wound dressing ${ }^{[13]}$. $\mathrm{NaCMC}$ can also be blended with polyethylene glycol and crosslinked with citric acid for dressing purposes, showing no cytotoxicity ${ }^{[14]}$. In order to present antibacterial properties, $\mathrm{NaCMC}$ hydrogels can be loaded with drugs. For example, $\mathrm{NaCMC}$ gels can be crosslinked with citric acid and loaded with MCM-41 mesoporous silica nanoparticles containing tetracycline (antibiotic), where higher particle content led to higher $S$. aureus inhibition ${ }^{[15]}$. In another study, $\mathrm{NaCMC}$ was blended to PVA to physically (freeze-thawing) form hydrogels loaded with sodium fucidate, where the addition of $\mathrm{NaCMC}$ increased the gels swelling capacity, vapor transmission rate and porosity ${ }^{[16]}$. PVA-NaCMC-sodium fucidate hydrogel showed faster healing compared to a PVA-NaCMC gel ${ }^{[17]}$.

Gelatin is a water-soluble protein obtained from the thermal denaturation of collagen. Gelatins with high levels of amino acids present high gel strength and melting point ${ }^{[18]}$. Gelatin is biocompatible, biodegradable, it has the ability to form films, and is generally low cost. In order to avoid dissolution in aqueous fluids, gelatin hydrogels have to be crosslinked with glutaraldehyde, genipin or lactose. Gelatin hydrogels crosslinked with lactose have been investigated as wound dressing materials ${ }^{[19]}$. Chitosan/gelatin crosslinked hydrogels were loaded with phenols from Hamamelis virginiana and showed activity against $P$. aeruginosa and $S$. aureus ${ }^{[20]}$. Superabsorbent gels were prepared by esterification of PVA with gelatin ${ }^{[21]}$. Chitosan/gelatin/PVA irradiated hydrogels for wound dressing applications presented swelling capacity, adequate vapor transmission rate and mechanical properties ${ }^{[22]}$. PVA/chitosan/gelatin hydrogels loaded with PCL microspheres containing bFGF and BSA (protein) showed no cytotoxicity, and an improved healing rate, while chitosan improved the antimicrobial properties ${ }^{[23]}$.
Honey is a bee-based product which can present more than 200 constituent components, mainly carbohydrates (most of them monosaccharides, e.g. fructose, glucose, sucrose), proteins, organic acids, vitamins and phenolic compounds. Honey's antimicrobial characteristics are related to the $\mathrm{H}_{2} \mathrm{O}_{2}$ produced by enzymatic activity and to the action of complex phenols and organic acids (flavonoids) ${ }^{[24,25]}$. The honey composition is influenced by the flower types visited by bees, the soil composition, bee species and climatic conditions. Brazilian honey presents a considerable variability, since the local flora and climate change all over the country. The honey's consistency, color, odor, taste and scent are constant physical-chemical characteristics in monoflower honeys. Honey's phenolic substances and flavonoids are responsible by pharmacological properties, e.g. antimicrobian and antioxidant activities ${ }^{[26]}$. Wounded rats treated with Brazilian honey (from southwest region of Brazil) presented fastest recovery than the control group, it also treated the wounds infection ${ }^{[27]}$. Brazilian honey, also from the southwest, was tested against $S$. aureus microorganisms and it showed antimicrobial activity, due to its phenolic compounds $^{[28]}$. Brazilian honey shows potential to be used as wound healing agent.

Honey has been successfully incorporated in hydrogels. For example, a chitosan dressing containing $75 \%$ honey enhanced tissue regeneration ${ }^{[29]}$. A pectin-honey hydrogel promoted faster wound healing than a control ${ }^{[30]}$. PVA crosslinked with borax and loaded with honey promoted the proliferation of cells, with swelling, and permeability properties considered adequate for moderate exudative wounds ${ }^{[31]}$. Gelatin-chitosan hydrogels loaded with compounds from manuka honey presented antibacterial activity, a high wound healing rate and the absorption of exudates ${ }^{[32]}$. Gelatin-chitosan-honey hydrogel was effective against $\mathrm{S}$. aureus and E. coli and stimulated burns healing ${ }^{[33]}$. PVP-agar-Peg gels containing $6 \%$ of honey acceletrated rats wounds contraction ${ }^{[34]}$; PVA/ chitosan/montmorillonite gels loaded with $15 \%$ Iranian honey showed potential to absorb exudate and efficient wound healing ${ }^{[35]}$; acrylamide hydrogels were loaded with different amounts of Indian honey (5-15\%), but the gel containing $10 \%$ honey was considered the best one, due to optimized tensile strength and swelling capacity ${ }^{[36]}$; carbopol 934 and chitosan gels containing 75\% Egyptian honey presented high burning healing rate ${ }^{[32]}$.

The goal of the present work was to develop layered PVA, PVA-honey (PVA-H), PVA-NaCMC (PVA-CMC), PVA-NaCMC-honey (PVA-CMC-H), PVA-gelatin (PVA-G), PVA-gelatin-honey (PVA-G-H) hydrogels and characterise their physico-chemical and functional properties in order to gain insights into their potential development as woundcare biomaterials.

\section{Materials and Methods}

\subsection{Sample preparation}

The samples were manufactured by the dissolution of PVA (Sigma-Aldrich, Mw: 85,000-124,000 Da, 99+\% hydrolyzed) at $90{ }^{\circ} \mathrm{C}$ under mechanical stirring for $4 \mathrm{~h}$ according to Table 1. For each PVA blend without honey, the amount of water used was split in half to separately dissolve 
Table 1. Samples composition.

\begin{tabular}{|c|c|c|c|c|c|}
\hline Sample & PVA & $\mathrm{NaCMC}$ & gelatin & honey & $\mathrm{H}_{2} \mathrm{O}$ \\
\hline PVA (3 layers) & $10 \mathrm{~g}$ & - & - & - & $100 \mathrm{~mL}$ \\
\hline PVA-CMC (3 layers) & $8 g$ & $2 \mathrm{~g}$ & - & - & $100 \mathrm{~mL}$ \\
\hline PVA-G (3 layers) & $8 g$ & - & $2 \mathrm{~g}$ & - & $100 \mathrm{~mL}$ \\
\hline PVA-H - $1^{\text {st }}$ layer & $10 \mathrm{~g}$ & - & - & - & $100 \mathrm{~mL}$ \\
\hline PVA-H $-2^{\text {nd }}$ layer & $10 \mathrm{~g}$ & - & - & $10 \mathrm{~mL}$ & $90 \mathrm{~mL}$ \\
\hline PVA-H $-3^{\text {rd }}$ layer & $10 \mathrm{~g}$ & - & - & $5 \mathrm{~mL}$ & $95 \mathrm{~mL}$ \\
\hline PVA-CMC-H - $1^{\text {st }}$ layer & $8 g$ & $2 \mathrm{~g}$ & - & - & $100 \mathrm{~mL}$ \\
\hline PVA-CMC-H $-2^{\text {nd }}$ layer & $8 g$ & $2 \mathrm{~g}$ & - & $10 \mathrm{~mL}$ & $90 \mathrm{~mL}$ \\
\hline PVA-CMC-H $-3^{\text {rd }}$ layer & $8 g$ & $2 \mathrm{~g}$ & - & $5 \mathrm{~mL}$ & $95 \mathrm{~mL}$ \\
\hline PVA-G-H - $1^{\text {st }}$ layer & $8 g$ & - & $2 \mathrm{~g}$ & - & $100 \mathrm{~mL}$ \\
\hline PVA-G-H $-2^{\text {nd }}$ layer & $8 g$ & - & $2 \mathrm{~g}$ & $10 \mathrm{~mL}$ & $90 \mathrm{~mL}$ \\
\hline PVA-G-H $-3^{\text {rd }}$ layer & $8 g$ & - & $2 g$ & $5 \mathrm{~mL}$ & $95 \mathrm{~mL}$ \\
\hline
\end{tabular}

the PVA and either NaCMC (Sigma-Aldrich, average Mw $\sim 250,000$, degree of substitution 0.9) or Gelatin (from bovine skin, Sigma-Aldrich, Type B). The resulting solutions were then mixed together after each solution had reached room temperature (under stirring). The $\mathrm{NaCMC}$ was dissolved in water under stirring at room temperature for $2 \mathrm{~h}$. Gelatin was dissolved at $60{ }^{\circ} \mathrm{C}$ under stirring for $4 \mathrm{~h}$.

The samples were prepared in three steps using 24-well plates. The composition of each layer of the samples without honey was similar (PVA or PVA-CMC or PVA-G). The first layer was obtained by pouring $1 \mathrm{~mL}$ of the polymer solution or the blend solution per well followed by a freeze-thaw cycle (each freeze-thawing cycle was to submit the sample to $1 \mathrm{~h}$ at $-18^{\circ} \mathrm{C}$ and $30 \mathrm{~min}$ at room temperature). The second layer $(1 \mathrm{~mL} /$ well) was subsequently added and freezethawed, followed by the addition and freeze-thawing of the third layer. The first layer was therefore subjected to 3 freeze-thawing cycles, the second layer to 2 cycles and the third layer to 1 cycle.

For the samples that were to contain honey (a commercial Brazilian honey from Southeast region, characterized as "silvestre" honey), the polymers were dissolved in the designated amounts of water from Table 1 following the procedures previously described. Honey was then added to the polymer solution or to the blend solution, according to the quantities indicated in Table 1, at room temperature under mechanical stirring for 5 minutes. The first layer of these samples was either pure PVA or a PVA based polymer blend without honey and had experienced 3 freeze-thawing cycles. The second layer was the polymer/blend with $10 \%$ honey, submitted to 2 freeze-thawing cycles; and the third layer was polymer/blend with $5 \%$ honey, submitted to 1 freeze-thawing cycle. All the samples were dried in oven at $50{ }^{\circ} \mathrm{C}$ for $24 \mathrm{~h}$. Regarding honeys' thermal degradation, honey samples treated at $23{ }^{\circ} \mathrm{C}$ for short times did not degrade, but the same behavior was not observed for samples heated at $95{ }^{\circ} \mathrm{C}$, although antiocidant activity might increase with the heating temperature ${ }^{[34]}$. Heat treated honey might present hydroxymethylfurfural, which should be lower than $80 \mathrm{mg} / \mathrm{kg}$ in tropical honeys, since it is toxic and carcinogenic. In addition, tropical honeys can present fermentation when heat treated, but it can be prevented by heating honey at $60-70{ }^{\circ} \mathrm{C}$ for $10 \mathrm{~min}$ or at $60-65{ }^{\circ} \mathrm{C}$ for $30 \mathrm{~min}^{[35]}$. The drying temperature was low to preserve honey activities, although honey samples autoclaved at $121^{\circ} \mathrm{C}$ could maintain its properties ${ }^{[27]}$.

\subsection{Physico-chemical analysis}

The physic-chemical analysis of the samples was performed by Fourier Transformed Infrared Spectroscopy (FTIR), equipment VERTEX-70 (UFRRJ), 32 scans per sample, from $4000 \mathrm{~cm}^{-1}$ to $600 \mathrm{~cm}^{-1}$. Samples representing each layer were prepared separately and submitted to the proper number of freeze-thawing cycles separately and then dried to be evaluated by FTIR. The multi-layered samples were also evaluated by FTIR.

\subsection{Thermal analysis}

The samples were analysed by Differential Scanning Calorimetry (DSC), where approximately $5 \mathrm{mg}$ of each sample composition was submitted to $10^{\circ} \mathrm{C} / \mathrm{min}$ of heat flow from room temperature to $240{ }^{\circ} \mathrm{C}$ using a DSC Q200 TA Instruments equipment (EMBRAPAAgroindustry). The transition temperatures of the samples (glass transition temperature - $\mathrm{T}_{\mathrm{g}}$, melting temperature - Tm) were obtained using the second cycle of heating to overcome the samples' thermal history. The samples degree of crystallinity (Xc) was calculated by

$$
X_{c}=100^{\Delta H_{m}} / \Delta H_{m 100}
$$

The $\Delta \mathrm{H}_{\mathrm{m}}$ is the enthalpy of melting related to the samples at the PVA melting temperature and $\Delta \mathrm{H}_{\mathrm{m} 100}$ is the enthalpy of melting related to PVA $100 \%$ crystalline, $138.6 \mathrm{~J} / \mathrm{g}^{[28]}$.

\subsection{In vitro analysis}

The swelling tests proceeded in saline solution at room temperature. For each sample composition, 5 samples were cut (samples weight was standardized among the ones with the same composition) and immersed in saline solution $(20 \mathrm{~mL}$ per sample, used to mimic the body fluids). The samples were removed from the saline solution at regular intervals ( $30 \mathrm{~min}, 1 \mathrm{~h}, 2 \mathrm{~h}, 3 \mathrm{~h}, 4 \mathrm{~h}, 24 \mathrm{~h}, 48 \mathrm{~h}, 72 \mathrm{~h}$ and $96 \mathrm{~h}$ ). The adsorbed fluid was removed using filter paper and the samples were weighed and then returned to the media. The swelling degree (SD) was calculated according to

$$
S D=100^{\left(W_{S}-W_{D B}\right)} / W_{D B}
$$


$\mathrm{W}_{\mathrm{DB}}$ is the weight of dried samples before swelling; $\mathrm{W}_{\mathrm{S}}$ is the weight of the swelled samples.

At the end of the 4 days of immersion, the samples were dried in oven at $50{ }^{\circ} \mathrm{C}$ for $24 \mathrm{~h}$ and weighed to calculate the sample gel fraction (GF)

$$
G F=100^{W_{D}} / W_{D B}
$$

$\mathrm{W}_{\mathrm{D}}$ is the weight of the dried samples after swelling) and weight loss (WL)/biodegradability ${ }^{[34]}$,

$$
W L=100\left(W_{D B}-W_{D}\right) / W_{D B}
$$

For microbiological analysis, the ASTM E2180- 07 standard was adapted. A suspension of Staphylococcus aureus cells (ATCC 6538) was prepared (guaranteeing that the suspension reached 0.5 in the MacFarland scale), which correspond to $10^{8}$ colony forming unit (UFC) $/ \mathrm{mL}$. The agar paste received $1 \mathrm{~mL}$ of the mentioned suspension, where the agar paste total amount of microrganisms were $10^{6} \mathrm{UFC} / \mathrm{mL}$. Each sample was placed in an empty well of 24 wells flat bottom polystyrene plate, and each well received $200 \mu \mathrm{L}$ of the agar paste containing $S$. aureus (where duplicates for each samples composition were evaluated). The plates were incubated at $30{ }^{\circ} \mathrm{C}$ for $24 \mathrm{~h}$. After incubation, the media in contact with samples were placed in Falcon tubes. After that, different amounts of buffer solution were added to prepare decimal dilutions of the media in contact with samples and to subsequently, count the colony forming units (cfu) by the micro dropping technique. The bacterial calculation was performed using the optical microscope (equipment Olympus). The reduction calculation was based on ASTM Standard 20170504.

\section{Results and Discussions}

It was not possible to distinguish the samples layers, indicating that the system might behave homogeneously. All samples, containing honey or not, presented homogeneous morphology, similar to PVA-H, Figure 1.

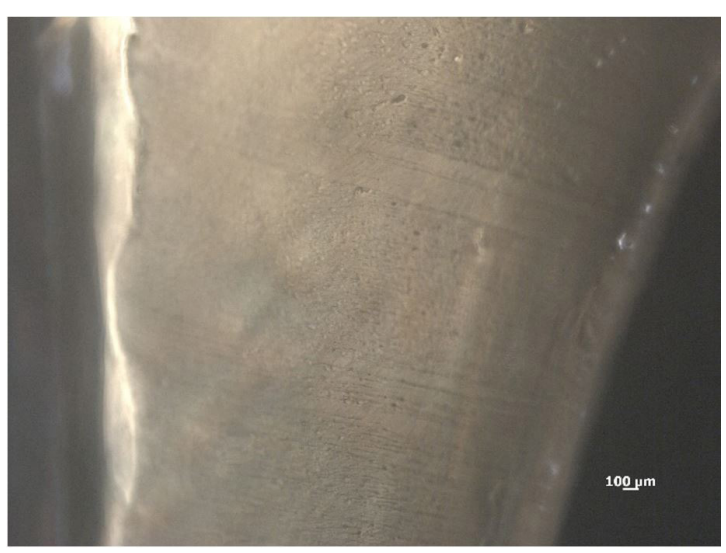

Figure 1. PVA-H sample section.

\subsection{Physico-chemical analysis}

The FTIR spectra of all samples are shown in Figure 2. Each layer of PVA presented similar FTIR spectra of the three-layered sample. Nonetheless, the band at $1142 \mathrm{~cm}^{-1}$, related to the formation of PVA crystallites (intra- and intermolecular hydrogen bonding between the chains originated by hydrophilic forces) ${ }^{[7]}$, presented lower transmittance with increasing numbers of freeze-thawing cycles, indicating the contribution of the freeze-thawing process to the formation of PVA crystals. There were (in all PVA layers) bands at: $3273 \mathrm{~cm}^{-1}(\mathrm{OH} \text { hydrogen bonds })^{[7]}$; $2941 \mathrm{~cm}^{-1}$ and $2909 \mathrm{~cm}^{-1}, v(\mathrm{C}-\mathrm{H})$ alkyl ${ }^{[7]} ; 1652 \mathrm{~cm}^{-1}, v(\mathrm{C}=\mathrm{O}-$, from residual aldehyde $)^{[35,36]} ; 1563 \mathrm{~cm}^{-1}$ and $1237 \mathrm{~cm}^{-1}$, $v(\mathrm{C}=\mathrm{C}-)^{[35]} ; 1411 \mathrm{~cm}^{-1}, \delta(-\mathrm{CH})^{[37]} ; 1380 \mathrm{~cm}^{-1}, \omega(\mathrm{C}-\mathrm{H})^{[38]}$; $1329 \mathrm{~cm}^{-1}, \delta(\mathrm{CH}+\mathrm{OH})^{[35]} ; 1089 \mathrm{~cm}^{-1}, v(\mathrm{C}-\mathrm{O})^{[39]} ; 916 \mathrm{~cm}^{-1}$, $\delta\left(-\mathrm{CH}_{2}\right)^{[39]}$; and $835 \mathrm{~cm}^{-1}, \rho(-\mathrm{CH})^{[39]}$.

The previously reported PVA bands were also observed in the PVA-CMC as well as the overlapping bands of $\mathrm{NaCMC}$, showing the dispersion of $\mathrm{NaCMC}$ in the PVA matrix ${ }^{[40]}$; a shoulder at $2855 \mathrm{~cm}^{-1}, v(\mathrm{C}-\mathrm{H})^{[41]}, 1585 \mathrm{~cm}^{-1}$ (non-hydrated $\mathrm{C}=\mathrm{O}$ of COO- group) ${ }^{[42]} ; 1415 \mathrm{~cm}^{-1}, v(\mathrm{COO}-) ; 1325 \mathrm{~cm}^{-1}$, $\delta(\mathrm{C}-\mathrm{H})$ of methyl groups; $1080 \mathrm{~cm}^{-1} v(\mathrm{C}-\mathrm{O})^{[43]}$. The band at $1652 \mathrm{~cm}^{-1}(\mathrm{C}=\mathrm{O})$ is absent in the sample PVA-CMC ${ }^{[35]}$. The band at $1560 \mathrm{~cm}^{-1}$ (carbonyl group) in the PVA-CMC sample has a different shape compared to the same band in the PVA sample, indicating a change in the balance of free associated carbonyl groups. It could relate to the polymers miscibility, although displacement of the bands related to the crystallinity of PVA $\left(1142 \mathrm{~cm}^{-1}, v(\mathrm{C}-\mathrm{C})\right)$ and of $\mathrm{NaCMC}$ $\left(1372 \mathrm{~cm}^{-1}, \delta(\mathrm{CH})\right)$ and displacement of the $\mathrm{NaCMC}$ $\beta$-glucosidic groups were not identified. As expected, the PVA crystallinity index (ratio between the absorbance of the band at $1142 \mathrm{~cm}^{-1}$ and the band at $2905 \mathrm{~cm}^{-1}$ ) is lower in the blend, $\mathrm{I}_{\mathrm{PVA}}$ is $\sim 1.45$ and $\mathrm{I}_{\mathrm{PVA}-\mathrm{CMC}}$ is $\sim 1.36$, where the presence of NaCMC diminishes the PVA chains ability to pack into crystals ${ }^{[43]}$. The PVA-CMC layers revealed that the increase of freeze-thawing cycles displaced the band at $1593 \mathrm{~cm}^{-1}\left(\mathrm{NaCMC}\right.$ 's $\left.v(-\mathrm{COO})^{[44]}\right)$ to $1566 \mathrm{~cm}^{-1}$, which indicate the effectiveness of the "crosslinking"[45]. In addition, the two bands at $1087 \mathrm{~cm}^{-1}\left(\mathrm{PVA}\right.$ 's $\left.\delta(\mathrm{C}-\mathrm{O}-\mathrm{H})^{[46]}\right)$ and at $1060 \mathrm{~cm}^{-1}\left(\mathrm{NaCMC}\right.$ 's $\left.v\left(\mathrm{OCH}-\mathrm{O}-\mathrm{CH}_{2}\right)^{[47]}\right)$ cannot be distinguished in layers submitted to more freeze-thawing cycles, where only one band at $1087 \mathrm{~cm}^{-1}$ can be observed.

The PVA-G sample presented some differences when compared to the PVA sample, e.g. the band at $1646 \mathrm{~cm}^{-1}$ was more intense in the PVA-G sample, which could be due to the gelatin $v(\mathrm{C}=\mathrm{O})^{[38]}$. There was a band at $1169 \mathrm{~cm}^{-1}$ in the PVA-G sample (absent in the PVA sample); the PVA bands at $1142 \mathrm{~cm}^{-1}$ and at $1089 \mathrm{~cm}^{-1}$ were displaced to $1136 \mathrm{~cm}^{-1}$ and to $1101 \mathrm{~cm}^{-1}$ in the PVA-G sample, respectively. The gelatin bands displacement towards higher wavenumbers could be related to reaction products, e.g. from $1680 \mathrm{~cm}^{-1}$ to $1758 \mathrm{~cm}^{-1}$ would represent the formation of esterified product ${ }^{[21]}$. There were bands at $640 \mathrm{~cm}^{-1}$ and at $612 \mathrm{~cm}^{-1}$ in the PVA-G sample, while there was no band in this region in the PVA sample. A band at $670 \mathrm{~cm}^{-1}$ would be attributed to the gelatin $\gamma(\mathrm{N}-\mathrm{H})$, although bands observed at lower wavelengths were not reported to gelatin ${ }^{[38]}$. The PVA-G layers revealed similar bands to those of the whole PVA-G sample. 

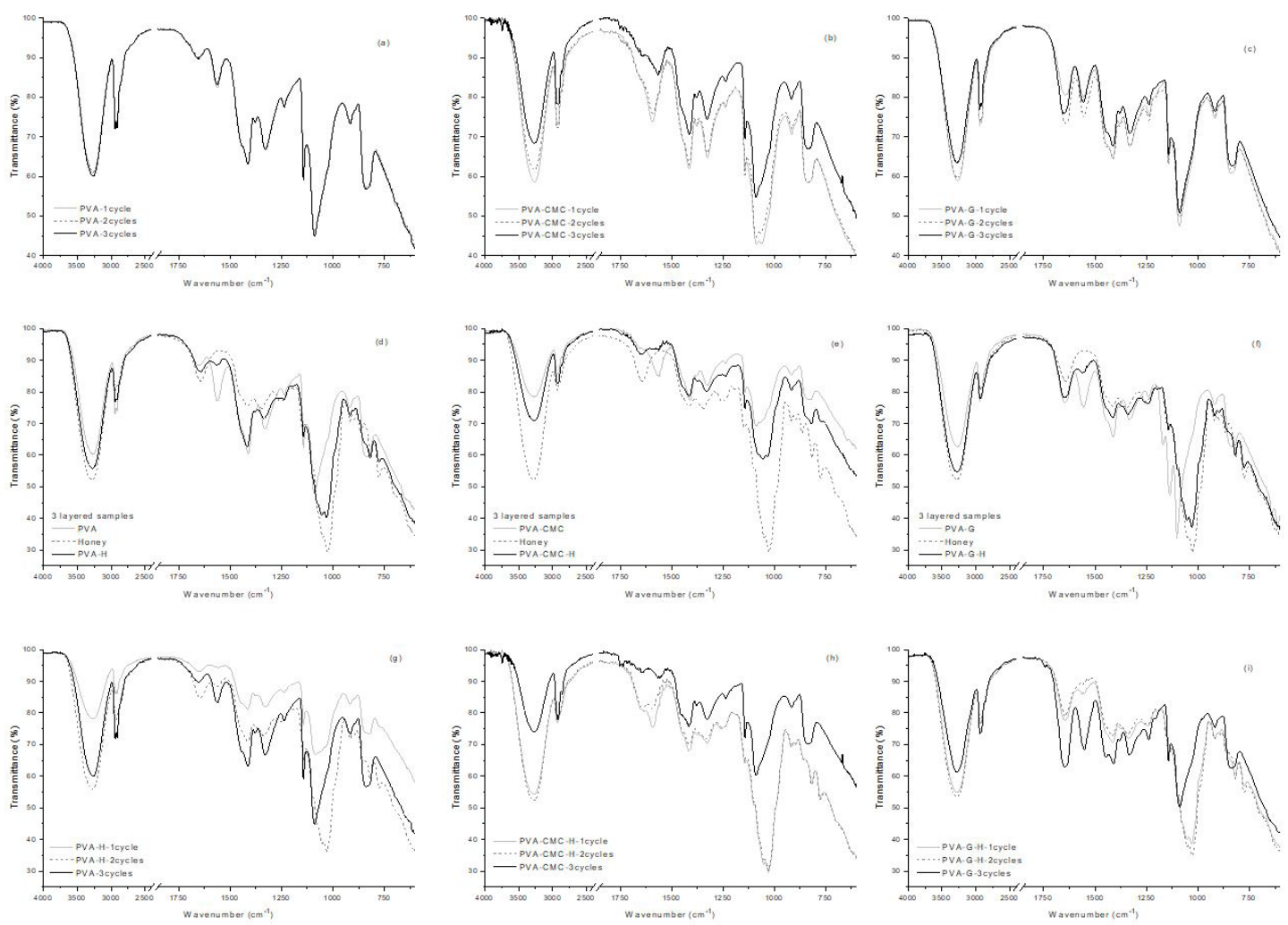

Figure 2. FTIR spectra of: (a) PVA layers; (b) PVA-CMC layers; (c) PVA-G layers; (d) PVA 3-layered sample, honey and PVA-H 3-layered sample; (e) PVA-CMC 3-layered sample, honey and PVA-CMC-H 3-layered sample; (f) PVA-G 3-layered sample, honey and PVA-G-H 3-layered sample; (g) PVA-H layers; (h) PVA-CMC-H layers; (i) PVA-G-H layers.

The PVA-H sample presents bands related to PVA, e.g. $3275 \mathrm{~cm}^{-1}, 2940 \mathrm{~cm}^{-1}, 2910 \mathrm{~cm}^{-1}, 1564 \mathrm{~cm}^{-1}, 1379 \mathrm{~cm}^{-1}$, $1239 \mathrm{~cm}^{-1}, 1143 \mathrm{~cm}^{-1}$. Nonetheless, some of its bands can be related to the presence of honey in the samples, e.g. at $1646 \mathrm{~cm}^{-1}\left(v(\mathrm{C}-\mathrm{H})\right.$ of carboxylic acids, $v\left(\mathrm{NH}_{3}\right)$ of free amino acids, water $\left.\delta(\mathrm{OH})^{[48]}\right), 1417 \mathrm{~cm}^{-1}(\delta(\mathrm{O}-\mathrm{H})$ of the $\mathrm{C}-\mathrm{OH}$ group and $\delta(\mathrm{C}-\mathrm{H})$ of the alkenes $\left.{ }^{[48]}\right), 775 \mathrm{~cm}^{-1}$ (saccharide configuration; anomeric region of carbohydrates vibration or $\left.\delta(\mathrm{C}-\mathrm{H})^{[49]}\right)$. In addition, some of the honey bands are slightly displaced in the PVA-H sample, e.g. the bands at $1054 \mathrm{~cm}^{-1}(v(\mathrm{C}-\mathrm{O})$ of the $\mathrm{C}-\mathrm{OH}$ group and carbohydrate structure's $\left.v(\mathrm{C}-\mathrm{C})^{[48]}\right) ; 1030 \mathrm{~cm}^{-1}$ (vibration of the $\mathrm{C}-\mathrm{OH}$ group, carbohydrate structure's $v(\mathrm{C}-\mathrm{C})$ and $v(\mathrm{C}-\mathrm{O})$, phenol's C-O vibration $\left.{ }^{[50]}\right) ; 898 \mathrm{~cm}^{-1} ; 874 \mathrm{~cm}^{-1}$, displaced by $\sim 9 \mathrm{~cm}^{-1} ; 819 \mathrm{~cm}^{-1}$, these last bands related to saccharide configuration and to anomeric region of carbohydrates vibration or $\delta(\mathrm{C}-\mathrm{H})^{[49]}$. Some of the PVA-H bands are located in between PVA bands position and honey bands position, e.g. the band at $1336 \mathrm{~cm}^{-1}$, which is in between the honey band at $1345 \mathrm{~cm}^{-1}$ (flavanol's and phenol's $\delta(\mathrm{O}-\mathrm{H}), \delta(\mathrm{C}-\mathrm{O}), \delta(\mathrm{C}-\mathrm{H})$ and $\left.\delta(\mathrm{C}=\mathrm{C})^{[50]}\right)$ and the PVA band at $\left.1329 \mathrm{~cm}^{-1[35]}\right)$; there is a shoulder at $1097 \mathrm{~cm}^{-1}$, between the PVA band at $1089 \mathrm{~cm}^{-1}\left(v(\mathrm{C}-\mathrm{O})^{[39]}\right)$ and the honey band at $1100 \mathrm{~cm}^{-1}\left(v(\mathrm{C}-\mathrm{O})\right.$ related to the $\mathrm{C}-\mathrm{O}-\mathrm{C}$ linkage $\left.{ }^{[48]}\right)$; $917 \mathrm{~cm}^{-1}$, which is between the PVA band at $916 \mathrm{~cm}^{-1[39]}$ and the honey band at $918 \mathrm{~cm}^{-1}$ (carbohydrate's $\delta(\mathrm{C}-\mathrm{H})^{[48]} ; \alpha$ and $\beta$ anomers' $\left.v_{\text {as }}(\mathrm{C}-\mathrm{O}-\mathrm{C})^{[51]}\right)$. These bands displacement and the bands located in between the original PVA and honey bands could indicate physical interaction (Van der Waals or hydrogen bonding) between PVA and honey.

Since the layers of the samples presented varied composition, they were examined separately. The layer containing $5 \%$ honey presented bands similar to the PVA-H whole sample previously described, but the bands at $1336 \mathrm{~cm}^{-1}$ and at $898 \mathrm{~cm}^{-1}$ (honey's bands ${ }^{[52]}$ ) were absent and a shoulder at $831 \mathrm{~cm}^{-1}$ (PVA's band ${ }^{[39]}$ ) was present; the band that should be at $1054-1030 \mathrm{~cm}^{-1}$ was displaced towards the PVA band $\left(1089 \mathrm{~cm}^{-1[39]}\right)$, it was at $1083 \mathrm{~cm}^{-1}$. The layer containing $10 \%$ honey also present the same bands as the PVA-H whole sample, but the bands at $2940 \mathrm{~cm}^{-1}$ and at $2910 \mathrm{~cm}^{-1}$ were absent. Nonetheless, there were bands at $2930 \mathrm{~cm}^{-1}$ (honey's band ${ }^{[48]}$ ), $1338 \mathrm{~cm}^{-1}, 1259 \mathrm{~cm}^{-1}$ (honey's band $\left.{ }^{[48]}\right), 1189 \mathrm{~cm}^{-1}$ (honey's band ${ }^{[50]}$ ). A slight displacement of PVA and of honey bands in the PVA-H layers could be observed with the increased honey content, which could indicate the effect of honey in the movement of PVA's functional groups and vice versa. The increased level of honey in the layer also revealed more honey bands in the FTIR spectrum, as expected.

The PVA-CMC-H sample presented the same bands as the PVA-CMC and that were previously described. In addition, there were bands related to honey, e.g. $2923 \mathrm{~cm}^{-1}$, $1417 \mathrm{~cm}^{-1}, 1056 \mathrm{~cm}^{-1}, 1035 \mathrm{~cm}^{-1}$ and $819 \mathrm{~cm}^{-1}$. These bands are slightly displaced in the PVA-CMC-H sample. The layer containing $10 \%$ honey and the layer with $5 \%$ 
honey presented similar bands to PVA-CMC-H whole sample previously described, although there were slight displacements of the bands with the addition of honey, e.g. the band at $1088 \mathrm{~cm}^{-1[39]}$ in PVA-CMC layer is broadened and shifted to $1074 \mathrm{~cm}^{-1}$ in the layer containing $10 \%$ honey. There is a band at $\sim 1592 \mathrm{~cm}^{-1}$ in the PVA-CMC-H layers that is absent in the PVA-CMC layer and in the honey spectrum. The presence of a new band could indicate new bonding between the polymers and honey ${ }^{[53]}$.

The PVA-G-H sample presented the previously described PVA bands; some gelatin bands, e.g. at $1551 \mathrm{~cm}^{-1}$ and at $1337 \mathrm{~cm}^{-1[54]}$; and some honey bands previously described, e.g. at $1052,1029,896,853,817,775 \mathrm{~cm}^{-1}$. Band displacement or the formation of bands related to a chemical reaction or interaction between honey and the polymers was not observed $^{[21]}$.

\subsection{Thermal analysis}

DSC analysis of the whole three-layer samples revealed that the addition of the polysaccharide $(\mathrm{NaCMC})$ diminished the sample $\mathrm{T}_{\mathrm{g}}$ and raised the sample $\mathrm{T}_{\mathrm{m}}$, compared to PVA, while $X c_{(P V A-C M C)}$ was lower than the $X c_{(P V A)}$ (Table 2). It suggests that the $\mathrm{NaCMC}$ chains do not contribute to polymer chain entanglement, probably working as a plasticizer in the amorphous region of the blend. In addition, the $\mathrm{NaCMC}$ diminished the degree of crystallinity, but more "perfect" crystals were formed (with a higher $\mathrm{T}_{\mathrm{m}}$ ). A similar effect was observed when gelatin was added to PVA, but the $T_{m}$ of PVA and PVA-G was similar, indicating that gelatin contributed only as a plasticizer and to diminish the sample's degree of crystallinity. The addition of honey to PVA diminished considerably the $\mathrm{T}_{\mathrm{g}}, \mathrm{T}_{\mathrm{m}}$ and the $\mathrm{Xc}$ of the samples, indicating that honey is a physical barrier to the interaction of polymer chains. The addition of both honey and either polysaccharide or protein to PVA led to the absence of crystallinity (there is no peak related to crystal formation). Nonetheless, compared to PVA-H, PVA-CMC-H and PVA-G-H both presented higher $\mathrm{T}_{\mathrm{g}}$, indicating that in the presence of the coupled materials the amorphous chains need more energy to gain movement. The $\mathrm{T}_{\mathrm{g}}$ and $\mathrm{T}_{\mathrm{m}}$ altering with the addition of $\mathrm{NaCMC}$ or honey could indicate miscibility and interaction between the material ${ }^{[55,56]}$. The addition of gelatin altered the PVA $\mathrm{T}_{\mathrm{g}}$ and $\mathrm{Xc}$ also due to the miscibility of the polymers which disorganize the chains packing ${ }^{[38]}$.

\subsection{In vitro analysis}

All the samples' swelling degree tests presented a similar trend (Figure 3), where there is a stretching of the network by the fluid's initial diffusion, followed by a plateau in the curves, where the polymers network reaches stability/ equilibrium, when the elastic forces and the osmotic forces on the network are balanced ${ }^{[57]}$. Although some samples presented significant differences between the first hours of swelling $(p<0.05)$, the samples reached swelling equilibrium in $24 \mathrm{~h}$ of immersion.

There was a significant difference of the equilibrium of swelling degree (SD) between all the samples, although the SD of the samples PVA and PVA-CMC-H can be considered the same. In general, it can be observed that samples containing honey swelled less than samples without honey ${ }^{[58]}$, probably because honey occupies network pores created by the ice during freeze-thawing, filling space that could have been available to the saline solution ${ }^{[59]}$. PVA samples swelled less than PVA-G samples (which have a low degree of crystallinity compared to PVA), and these in turn swelled less than PVA-CMC samples (which have an even lower degree of crystallinity). Samples that are less crystalline present more amorphous phase and thereby stretch more with fluid ingress, and therefore swell more ${ }^{[60,61]}$.

The gel fraction (GF) of all the samples without honey (Figure 3) can be considered similar ( $p>0.05$ ). Although the addition of natural polymers altered the degree of crystallinity of the samples, the amorphous chain entanglements and the crystallites formed in freeze-thawing maintained the samples' structural integrity ${ }^{[62]}$. The addition of honey decreased the gel fraction of the samples $(p<0.05)$. The gel fraction property is related to the hydrogel's crosslinked polymers chains that remain insoluble when immersed in aqueous fluid. The PVA-H GF is significantly higher than the PVA-CMC-H GF which is, in turn, significantly higher than the PVA-G-H, GF $(p<0.05)$. The GF of the honey samples diminish in accordance with the decrease in the samples' degree of crystallinity, indicating that the samples crystallites work as physical crosslinking points. The addition of the natural polymers, as well as the addition of honey, diminishes the gels' degree of crystallinity, diminishing the gels' $\mathrm{GF}^{[63,64]}$.

The samples without honey presented similar weight loss ( $p>0.05)$, Figure 3. The PVA samples weight loss (WL) could be due to biodegradation in saline: "hydrolytic cleavage of hydrogen bonding among -OH groups of PVA chains", as discussed by Kamoun et al. ${ }^{[65]}$. The weight

Table 2. Data regarding the samples degree of crystallinity $(\mathrm{Xc})$, glass transition temperature $\left(\mathrm{T}_{\mathrm{g}}\right)$, melting temperature $\left(\mathrm{T}_{\mathrm{m}}\right)$, swelling degree (SD), gel fraction (GF), weight loss (WL), S. aureus growth.

\begin{tabular}{|c|c|c|c|c|c|c|c|c|}
\hline \multirow{3}{*}{ Samples } & \multicolumn{3}{|c|}{ DSC } & \multicolumn{3}{|c|}{ Swelling } & \multicolumn{2}{|c|}{ S. aureus } \\
\hline & $\mathbf{T}_{\mathrm{g}}$ & $\mathbf{T}_{\mathrm{m}}$ & $\mathrm{Xc}$ & SD & GF & WL & \multirow{2}{*}{$\begin{array}{l}\text { Growth } \\
\text { (CFU/g) }\end{array}$} & \multirow{2}{*}{$\begin{array}{c}\text { Reduction } \\
(\%)\end{array}$} \\
\hline & \multicolumn{2}{|c|}{$\left({ }^{\circ} \mathrm{C}\right)$} & $(\%)$ & \multicolumn{3}{|c|}{ (\%) } & & \\
\hline PVA & 87 & 218 & 21 & $142 \pm 16$ & $89 \pm 1$ & $10 \pm 1$ & $5,5 \times 10^{6}$ & 0 \\
\hline PVA-H & 80 & 150 & 5 & $79 \pm 8$ & $45 \pm 2$ & $54 \pm 2$ & $5,7 \times 10^{6}$ & \\
\hline PVA-CMC & 69 & 223 & 19 & $363 \pm 16$ & $88 \pm 5$ & $11 \pm 5$ & $7,7 \times 10^{5}$ & 29.9 \\
\hline PVA-CMC-H & 85 & - & - & $113 \pm 22$ & $36 \pm 6$ & $63 \pm 6$ & $5,4 \times 10^{5}$ & \\
\hline PVA-G & 79 & 218 & 13 & $216 \pm 7$ & $86 \pm 1$ & $13 \pm 1$ & $8,7 \times 10^{6}$ & 14.9 \\
\hline PVA-G-H & 102 & - & - & $49 \pm 11$ & $22 \pm 1$ & $77 \pm 1$ & $7,4 \times 10^{6}$ & \\
\hline
\end{tabular}



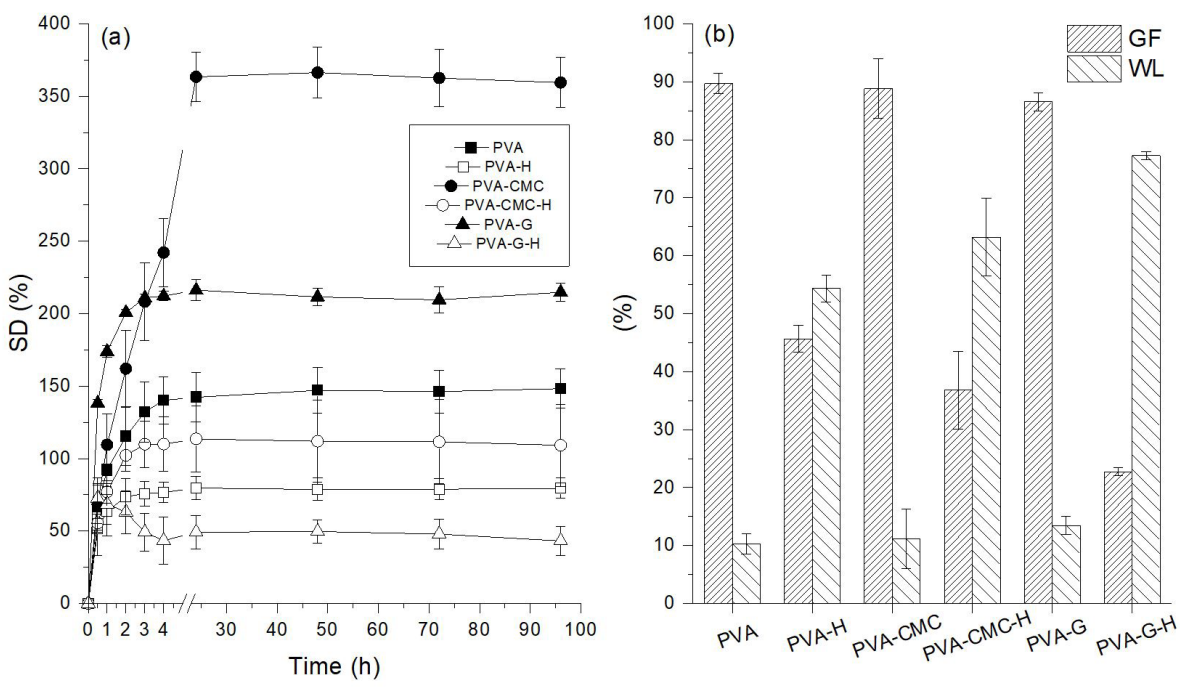

Figure 3. Samples (a) Swelling Degree and (b) Weight Loss and gel fraction.

loss of the PVA blends could be related to PVA hydrolytic cleavage and also to the solubility of the natural polymers in aqueous media ${ }^{[6-68]}$. The samples containing honey presented significantly higher weight loss/biodegradation than the samples without honey. The WL followed the trend: PVA-H $<$ PVA-CMC-H $<$ PVA-G-H $(\mathrm{p}<0.05)$, hypothesised to be due to degradation (due to chains leaching out by the saline solution) and honey delivery of both samples ${ }^{[69]}$. It is worth noting that only the three-layered samples were evaluated.

In this study, the PVA hydrogel can be considered a negative control (non-bactericidal) against gram-positive bacteria ( $S$. aureus), allowing bacteria to grow in its presence $^{[70]}$. The addition of honey inhibited the bacterial growth in the presence of the samples for PVA-CMC and PVA-G samples, Table 2. S. aureus attaches to proteins on the surface of collagen matrices and gelatin is a hydrolysed form of collagen ${ }^{[7]}$. Honey itself has a bactericidal effect due to its low water activity, the presence of $\mathrm{H}_{2} \mathrm{O}_{2}$ and its low $\mathrm{pH}^{[72]}$. The antibacterial effect on $\mathrm{S}$. aureus in wound healing hydrogels would depend on exceeding the minimum inhibitory concentration (MIC) of the honey with respect to the amount of honey in, and released from, the samples ${ }^{[73]}$. Several hydrogels containing honey present antibacterial activity ${ }^{[32,74]}$. The samples of the present work had $200 \mathrm{mg} / \mathrm{mL}$ of honey, but the MIC for this Brazilian honey might not be have been reached for the PVA-honey samples. The PVA-CMC-H and PVA-G-H samples presented activity against $S$. aureus relative to their counterparts with no honey ${ }^{[59]}$. It was observed a bactericidal effect. It is known that even low concentrations of honey can stimulate wound healing ${ }^{[75]}$.

\section{Conclusions}

It was observed that the addition of some materials to PVA diminishes the gels crystallinity and gel fraction (related to the degree of crosslinking of the gels), altering the samples ability to swell, where the samples with honey presented lower fluid uptake than samples without it, since honey can occupy and obstruct pores. Nonehteless, the samples containing honey presented significantly higher biodegradation (hydrolytic degradation/weight loss) than the samples without honey. The samples with $\mathrm{NaCMC}$ or gelatin and honey were the ones that presented the highest activity against $\mathrm{S}$. aureus relative to their honey-free counterparts, showing potential to be used as wound care materials.

\section{Acknowledgements}

The authors thank Conselho Nacional de Desenvolvimento Científico e Tecnológico - CNPq (funding/project 405922/2016-7) for the financial support, Fundação de Amparo à Pesquisa do Estado do Rio de Janeiro - FAPERJ, CAPES ("This study was financed in part by the Coordenação de Aperfeiçoamento de Pessoal de Nível Superior - Brasil (CAPES) - Finance Code 001"), professor Garrett Brian McGuinness and professor Mauricio Mancini, CETEM/UFRJ and EMBRAPA.

\section{References}

1. Simões, D., Miguel, S. P., Ribeiro, M. P., Coutinho, P., Mendonça, A. G., \& Correia, I. J. (2018). Recent advances on antimicrobial wound dressing: a review. European Journal of Pharmaceutics and Biopharmaceutics, 127, 130-141. http:// dx.doi.org/10.1016/j.ejpb.2018.02.022. PMid:29462687.

2. Tsao, C. T., Leung, M., Chang, J. Y., \& Zhang, M. (2014). A simple material model to generate epidermal and dermal layers in vitro for skin regeneration. Journal of Materials Chemistry B, Materials for Biology and Medicine, 2(32), 5256-5264. http://dx.doi.org/10.1039/C4TB00614C. PMid:25147728.

3. Lee, Y. H., Chang, J. J., Yang, M. C., Chien, C. T., \& Lai, W. F. (2012). Acceleration of wound healing in diabetic rats by layered hydrogel dressing. Carbohydrate Polymers, 88(3), 809-819. http://dx.doi.org/10.1016/j.carbpol.2011.12.045.

4. Morales Hurtado, M., de Vries, E. G., Zeng, X., \& van der Heide, E. (2016). A tribo-mechanical analysis of PVA-based building-blocks for implementation in a 2-layered skin model. Journal of the Mechanical Behavior of Biomedical Materials, 
62,319-332. http://dx.doi.org/10.1016/j.jmbbm.2016.05.001. PMid:27236420.

5. Tavakoli, J., Mirzaei, S., \& Tang, Y. (2018). Cost-effective double-layer hydrogel composites for wound dressing applications. Polymers, 10(3), 305. http://dx.doi.org/10.3390/ polym10030305. PMid:30966340.

6. Jiang, S., Liu, S., \& Feng, W. (2011). PVA hydrogel properties for biomedical application. Journal of the Mechanical Behavior of Biomedical Materials, 4(7), 1228-1233. http://dx.doi. org/10.1016/j.jmbbm.2011.04.005. PMid:21783131.

7. Reis, E. F., Campos, F. S., Lage, A. P., Leite, R. C., Heneine, L. G., Vasconcelos, W. L., Lobato, Z. I. P., \& Mansur, H. S. (2006). Synthesis and characterization of poly (vinyl alcohol) hydrogels and hybrids for rMPB70 protein adsorption. Materials Research, 9(2), 185-191. http://dx.doi.org/10.1590/S151614392006000200014.

8. Tontowi, A. E., Perkasa, D. P., Siswomihardjo, W., \& Darwis, D. (2016). Effect of polyvinyl alcohol (PVA) blending and gamma irradiation on compressive strength of FHAp/FGel composite as candidate of scaffold. IACSIT International Journal of Engineering and Technology, 8(1), 108-116.

9. Gupta, S., Webster, T. J., \& Sinha, A. (2011). Evolution of PVA gels prepared without crosslinking agents as a cell adhesive surface. Journal of Materials Science: Materials in Medicine, 22(7), 1763-1772. http://dx.doi.org/10.1007/s10856-011-43432. PMid:21643819.

10. El-Fawal, G. F., Yassin, A. M., \& El-Deeb, N. M. (2017). The novelty in fabrication of poly vinyl alcohol/ $\kappa$-carrageenan hydrogel with Lactobacillus bulgaricus extract as antiinflammatory wound dressing agent. AAPS PharmSciTech, 18(5), 1605-1616. http://dx.doi.org/10.1208/s12249-016-0628-6. PMid:27620196.

11. Choi, J. S., Kim, D. W., Kim, D. S., Kim, J. O., Yong, C. S., Cho, K. H., Youn, Y. S., Jin, S. G., \& Choi, H. G. (2016). Novel neomycin sulfate-loaded hydrogel dressing with enhanced physical dressing properties and wound-curing effect. Drug Delivery, 23(8), 2806-2812. http://dx.doi.org/10.3109/10717 544.2015.1089958. PMid:26394193.

12. Sannino, A., Demitri, C., \& Madaghiele, M. (2009). Biodegradable cellulose-based hydrogels: design and applications. Materials, 2(2), 353-373. http://dx.doi.org/10.3390/ma2020353.

13. Nayak, S., \& Kundu, S. C. (2014). Sericin-carboxymethyl cellulose porous matrices as cellular wound dressing material. Journal of Biomedical Materials Research: Part A, 102(6), 19281940. http://dx.doi.org/10.1002/jbm.a.34865. PMid:23853114.

14. Capanema, N. S. V., Mansur, A. A. P., Jesus, A. C., Carvalho, S. M., Oliveira, L. C., \& Mansur, H. S. (2018). Superabsorbent crosslinked carboxymethyl cellulose-PEG hydrogels for potential wound dressing applications. International Journal of Biological Macromolecules, 106, 1218-1234. http://dx.doi. org/10.1016/j.ijbiomac.2017.08.124. PMid:28851645.

15. Namazi, H., Rakhshaei, R., Hamishehkar, H., \& Kafil, H. S. (2016). Antibiotic loaded carboxymethylcellulose/MCM-41 nanocomposite hydrogel films as potential wound dressing. International Journal of Biological Macromolecules, 85, 327-334. http://dx.doi.org/10.1016/j.ijbiomac.2015.12.076. PMid:26740467.

16. Lim, S. J., Lee, J. H., Piao, M. G., Lee, M. K., Oh, D. H., Hwang, D. H., Quan, Q. Z., Yong, C. S., \& Choi, H. G. (2010). Effect of sodium carboxymethylcellulose and fucidic acid on the gel characterization of polyvinylalcohol-based wound dressing. Archives of Pharmacal Research, 33(7), 1073-1081. http:// dx.doi.org/10.1007/s12272-010-0714-3. PMid:20661718.

17. Lee, J. H., Lim, S. J., Oh, D. H., Ku, S. K., Li, D. X., Yong, C. S., \& Choi, H. G. (2010). Wound healing evaluation of sodium fucidate-loaded polyvinylalcohol/sodium carboxymethylcellulose- based wound dressing. Archives of Pharmacal Research, 33(7), 1083-1089. http://dx.doi.org/10.1007/s12272-010-0715-2. PMid:20661719.

18. Mariod, A. A., \& Adam, H. F. (2013). Review: Gelatin, source, extraction and industrial applications. Acta Scientiarum Polonorum. Technologia Alimentaria, 12(2), 135-147.

19. Etxabide, A., Vairo, C., Santos-Vizcaino, E., Guerrero, P., Pedraz, J. L., Igartua, M., de la Caba, K., \& Hernandez, R. M. (2017). Ultra thin hydro-films based on lactose-crosslinked fish gelatin for wound healing applications. International Journal of Pharmaceutics, 530(1-2), 455-467. http://dx.doi. org/10.1016/j.ijpharm.2017.08.001. PMid:28789885.

20. Rocasalbas, G., Francesko, A., Touriño, S., Fernández-Francos, X., Guebitz, G. M., \& Tzanov, T. (2013). Laccase-assisted formation of bioactive chitosan/gelatin hydrogel stabilized with plant polyphenols. Carbohydrate Polymers, 92(2), 989-996. http://dx.doi.org/10.1016/j.carbpol.2012.10.045. PMid:23399119.

21. Pal, K., Banthia, A. K., \& Majumdar, D. K. (2007). Preparation and characterization of polyvinyl alcohol-gelatin hydrogel membranes for biomedical applications. AAPS PharmSciTech, 8(1), 21. http://dx.doi.org/10.1208/pt080121. PMid:17408220.

22. Fan, L., Yang, H., Yang, J., Peng, M., \& Hu, J. (2016). Preparation and characterization of chitosan/gelatin/PVA hydrogel for wound dressings. Carbohydrate Polymers, 146, 427-434. http://dx.doi.org/10.1016/j.carbpol.2016.03.002. PMid:27112893.

23. Shamloo, A., Sarmadi, M., Aghababaie, Z., \& Vossoughi, M. (2018). Accelerated full-thickness wound healing via sustained bFGF delivery based on a PVA/chitosan/gelatin hydrogel incorporating PCL microspheres. International Journal of Pharmaceutics, 537(1-2), 278-289. http://dx.doi.org/10.1016/j. ijpharm.2017.12.045. PMid:29288809.

24. Martinotti, S., \& Ranzato, E. (2018). Honey, wound repair and regenerative medicine. Journal of Functional Biomaterials, 9(2), 34. http://dx.doi.org/10.3390/jfb9020034. PMid:29738478.

25. Meo, S. A., Al-Asiri, S. A., Mahesar, A. L., \& Ansari, M. J. (2017). Role of honey in modern medicine. Saudi Journal of Biological Sciences, 24(5), 975-978. http://dx.doi.org/10.1016/j. sjbs.2016.12.010. PMid:28663690.

26. Santos, A. M. N., Moreira, A. P. D., Carvalho, C. W. P., Luchese, R., Ribeiro, E., McGuinness, G. B., Mendes, M. F., \& Oliveira, R. N. (2019). Physically cross-linked gels of PVA with natural polymers as matrices for manuka honey release in wound-care applications. Materials, 12(4), 559. http://dx.doi. org/10.3390/ma12040559. PMid:30781788.

27. Mandal, S., DebMandal, M., Pal, N. K., \& Saha, K. (2010). Antibacterial activity of honey against clinical isolates of Escherichia coli, Pseudomonas aeruginosa and Salmonella enterica serovar Typhi. Asian Pacific Journal of Tropical Medicine, 3(12), 961-964. http://dx.doi.org/10.1016/S19957645(11)60009-6.

28. Guirguis, O. W., \& Moselhey, M. T. H. (2012). Thermal and structural studies of poly (vinyl alcohol) and hydroxypropyl cellulose blends. Nature and Science, 04(01), 57-67. http:// dx.doi.org/10.4236/ns.2012.41009.

29. El-Kased, R. F., Amer, R. I., Attia, D., \& Elmazar, M. M. (2017). Honey-based hydrogel: in vitro and comparative in vivo evaluation for burn wound healing. Scientific Reports, 7(1), 9692. http://dx.doi.org/10.1038/s41598-017-08771-8. PMid:28851905.

30. Giusto, G., Vercelli, C., Comino, F., Caramello, V., Tursi, M., \& Gandini, M. (2017). A new, easy-to-make pectin-honey hydrogel enhances wound healing in rats. BMC Complementary and Alternative Medicine, 17(1), 266. http://dx.doi.org/10.1186/ s12906-017-1769-1. PMid:28511700. 
31. Tavakoli, J., \& Tang, Y. (2017). Honey/PVA hybrid wound dressings with controlled release of antibioticsStructural, physicomechanical and in-vitro biomedical studies. Materials Science and Engineering C, 77, 318-325. http://dx.doi.org/10.1016/j. msec.2017.03.272. PMid:28532035.

32. Abd El-Malek, F. F., Yousef, A. S., \& El-Assar, S. A. (2017). Hydrogel film loaded with new formula from manuka honey for treatment of chronic wound infections. Journal of Global Antimicrobial Resistance, 11, 171-176. http://dx.doi.org/10.1016/j. jgar.2017.08.007. PMid:28830809.

33. Wang, T., Zhu, X. K., Xue, X. T., \& Wu, D. Y. (2012). Hydrogel sheets of chitosan, honey and gelatin as burn wound dressings. Carbohydrate Polymers, 88(1), 75-83. http://dx.doi.org/10.1016/j. carbpol.2011.11.069.

34. Oliveira, R. N., Paranhos da Silva, C. M., Moreira, A. P. D., Mendonça, R. H., Thiré, R. M., \& McGuinness, G. B. (2017). Comparative analysis of PVA hydrogels incorporating two natural antimicrobials: Punica granatum and Arnica montana tinctures. Journal of Applied Polymer Science, 134(41), 45392. http://dx.doi.org/10.1002/app.45392.

35. Oliveira, R. N., Rouzé, R., Quilty, B., Alves, G. G., Soares, G. D. A., Thiré, R. M. S. M., \& McGuinness, G. B. (2014). Mechanical properties and in vitro characterization of polyvinyl alcohol-nano-silver hydrogel wound dressings. Interface Focus, 4(1), 20130049. http://dx.doi.org/10.1098/rsfs.2013.0049. PMid:24501677.

36. Pietrucha, K., \& Verne, S. (2009). Synthesis and characterization of a new generation of hydrogels for biomedical applications. In Proceedings of the World Congress on Medical Physics and Biomedical Engineering (pp. 1-4). Berlin: Springer. http:// dx.doi.org/10.1007/978-3-642-03900-3_1.

37. Abureesh, M. A., Oladipo, A. A., \& Gazi, M. (2016). Facile synthesis of glucose-sensitive chitosan-poly(vinyl alcohol) hydrogel: drug release optimization and swelling properties. International Journal of Biological Macromolecules, 90, 75-80. http://dx.doi.org/10.1016/j.ijbiomac.2015.10.001. PMid:26459171

38. Pawde, S. M., \& Deshmukh, K. (2008). Characterization of polyvinyl alcohol/gelatin blend hydrogel films for biomedical applications. Journal of Applied Polymer Science, 109(5), 3431-3437. http://dx.doi.org/10.1002/app.28454.

39. Chen, X., Chen, C., Zhang, H., Huang, Y., Yang, J., \& Sun, D. (2017). Facile approach to the fabrication of 3D cellulose nanofibrils (CNFs) reinforced poly(vinyl alcohol) hydrogel with ideal biocompatibility. Carbohydrate Polymers, 173, 547-555. http://dx.doi.org/10.1016/j.carbpol.2017.06.036. PMid:28732898.

40. Ibrahim, M. M., Koschella, A., Kadry, G., \& Heinze, T. (2013). Evaluation of cellulose and carboxymethyl cellulose/ poly(vinyl alcohol) membranes. Carbohydrate Polymers, 95(1), 414-420. http://dx.doi.org/10.1016/j.carbpol.2013.03.012. PMid:23618287.

41. Hassan, E. A., Hassan, M. L., Moorefield, C. N., \& Newkome, G. R. (2015). New supramolecular metallo-terpyridine carboxymethyl cellulose derivatives with antimicrobial properties. Carbohydrate Polymers, 116, 2-8. http://dx.doi. org/10.1016/j.carbpol.2014.06.056. PMid:25458266.

42. Juncu, G., Stoica-Guzun, A., Stroescu, M., Isopencu, G., \& Jinga, S. I. (2016). Drug release kinetics from carboxymethylcellulosebacterial cellulose composite films. International Journal of Pharmaceutics, 510(2), 485-492. http://dx.doi.org/10.1016/j. ijpharm.2015.11.053. PMid:26688041.

43. Shehap, A. (2008). Thermal and spectroscopic studies of polyvinyl alcohol/sodium carboxy methyl cellulose blends. Egyptian Journal of Solid, 31(1), 75-91.
44. Ikhuoria, E. U., Omorogbe, S. O., Agbonlahor, O. G., Iyare, N. O., Pillai, S., \& Aigbodion, A. I. (2017). Spectral analysis of the chemical structure of carboxymethylated cellulose produced by green synthesis from coir fibre. Ciência e Tecnologia dos Materiais, 29(2), 55-62. http://dx.doi.org/10.1016/j. ctmat.2016.05.007.

45. Abou-Yousef, H., \& Kamel, S. (2015). High efficiency antimicrobial cellulose-based nanocomposite hydrogels. Journal of Applied Polymer Science, 132(31). http://dx.doi. org/10.1002/app.42327.

46. Chaturvedi, A., Bajpai, A. K., \& Bajpai, J. (2015). Preparation and characterization of poly(vinyl alcohol) cryogel-silver nanocomposites and evaluation of blood compatibility, cytotoxicity, and antimicrobial behaviors. Polymer Composites, 36(11), 1983-1997. http://dx.doi.org/10.1002/pc.23108.

47. Singh, R. K., \& Khatri, O. P. (2012). A scanning electron microscope based new method for determining degree of substitution of sodium carboxymethyl cellulose. Journal of Microscopy, 246(1), 43-52. http://dx.doi.org/10.1111/j.13652818.2011.03583.x. PMid:22150298.

48. Anjos, O., Campos, M. G., Ruiz, P. C., \& Antunes, P. (2015). Application of FTIR-ATR spectroscopy to the quantification of sugar in honey. Food Chemistry, 169, 218-223. http://dx.doi. org/10.1016/j.foodchem.2014.07.138. PMid:25236219.

49. Kędzierska-Matysek, M., Matwijczuk, A., Florek, M., Barłowska, J., Wolanciuk, A., Matwijczuk, A., Chruściel, E., Walkowiak, R., Karcz, D., \& Gładyszewska, B. (2018). Application of FTIR spectroscopy for analysis of the quality of honey. BIO Web of Conferences, 10, 02008. http://dx.doi.org/10.1051/ bioconf/20181002008.

50. Tahir, H. E., Xiaobo, Z., Zhihua, L., Jiyong, S., Zhai, X., Wang, S., \& Mariod, A. A. (2017). Rapid prediction of phenolic compounds and antioxidant activity of Sudanese honey using Raman and Fourier transform infrared (FT-IR) spectroscopy. Food Chemistry, 226, 202-211. http://dx.doi.org/10.1016/j. foodchem.2017.01.024. PMid:28254013.

51. Das, C., Chakraborty, S., Acharya, K., Bera, N. K., Chattopadhyay, D., Karmakar, A., \& Chattopadhyay, S. (2017). FT-MIR supported Electrical Impedance Spectroscopy based study of sugar adulterated honeys from different floral origin. Talanta, 171,327-334. http://dx.doi.org/10.1016/j.talanta.2017.05.016. PMid:28551147.

52. Gok, S., Severcan, M., Goormaghtigh, E., Kandemir, I., \& Severcan, F. (2015). Differentiation of Anatolian honey samples from different botanical origins by ATR-FTIR spectroscopy using multivariate analysis. Food Chemistry, 170, 234-240. http:// dx.doi.org/10.1016/j.foodchem.2014.08.040. PMid:25306340.

53. Yang, C., \& Wöll, C. (2017). IR spectroscopy applied to metal oxide surfaces: adsorbate vibrations and beyond. Advances in Physics: X, 2(2), 373-408. https://doi.org/10.1080/23746149. 2017.1296372.

54. Agarwal, T., Narayan, R., Maji, S., Behera, S., Kulanthaivel, S., Maiti, T. K., Banerjee, I., Pal, K., \& Giri, S. (2016). Gelatin/ Carboxymethyl chitosan based scaffolds for dermal tissue engineering applications. International Journal of Biological Macromolecules, 93(PtB), 1499-1506. http://dx.doi.org/10.1016/j. ijbiomac.2016.04.028. PMid:27086289.

55. Sudhamani, S., Prasad, M., \& Udaya Sankar, K. (2003). DSC and FTIR studies on Gellan and Polyvinyl alcohol (PVA) blend films. Food Hydrocolloids, 17(3), 245-250. http://dx.doi. org/10.1016/S0268-005X(02)00057-7.

56. Abdulkhani, A., Hojati Marvast, E., Ashori, A., Hamzeh, Y., \& Karimi, A. N. (2013). Preparation of cellulose/polyvinyl alcohol biocomposite films using 1-n-butyl-3-methylimidazolium chloride. International Journal of Biological Macromolecules, 
62,379-386. http://dx.doi.org/10.1016/j.ijbiomac.2013.08.050. PMid:24076203.

57. Ganji, F., Vasheghani-Farahani, S., \& Vasheghani-Farahani, E. (2010). Theoretical description of hydrogel swelling: a review. Iranian Polymer Journal, 19(5), 375-398.

58. Kouchak, M., Ameri, A., Naseri, B., \& Kargar Boldaji, S. (2014). Chitosan and polyvinyl alcohol composite films containing nitrofurazone: preparation and evaluation. Iranian Journal of Basic Medical Sciences., 17(1), 14-20. http://dx.doi. org/10.22038/ijbms.2014.2150. PMid:24592302.

59. Oliveira, R. N., Moreira, A. P. D., Thiré, R. M. S. M., Quilty, B., Passos, T. M., Simon, P., Mancini, M. C., \& McGuinness, G. B. (2017). Absorbent polyvinyl alcohol-sodium carboxymethyl cellulose hydrogels for propolis delivery in wound healing applications. Polymer Engineering and Science, 57(11), 12241233. http://dx.doi.org/10.1002/pen.24500.

60. Huang, M.-H., \& Yang, M.-C. (2008). Evaluation of glucan/ poly(vinyl alcohol) blend wound dressing using rat models. International Journal of Pharmaceutics, 346(1-2), 38-46. http:// dx.doi.org/10.1016/j.ijpharm.2007.06.021. PMid:17662545.

61. Wang, L.-C., Chen, X.-G., Zhong, D.-Y., \& Xu, Q.-C. (2007). Study on poly(vinyl alcohol)/carboxymethyl-chitosan blend film as local drug delivery system. Journal of Materials Science: Materials in Medicine, 18(6), 1125-1133. http:// dx.doi.org/10.1007/s10856-007-0159-5. PMid:17268861.

62. Ahmed, E. M. (2015). Hydrogel: preparation, characterization, and applications: a review. Journal of Advanced Research, 6(2), 105-121. http://dx.doi.org/10.1016/j.jare.2013.07.006. PMid:25750745.

63. Tahtat, D., Mahlous, M., Benamer, S., Nacer Khodja, A., Larbi Youcef, S., Hadjarab, N., \& Mezaache, W. (2011). Influence of some factors affecting antibacterial activity of PVA/Chitosan based hydrogels synthesized by gamma irradiation. Journal of Materials Science: Materials in Medicine, 22(11), 2505-2512. http://dx.doi.org/10.1007/s10856-011-4421-5. PMid:21870082.

64. El-Naggar, A. W. M., Senna, M. M., Mostafa, T. A., \& Helal, R. H. (2017). Radiation synthesis and drug delivery properties of interpenetrating networks (IPNs) based on poly(vinyl alcohol)/ methylcellulose blend hydrogels. International Journal of Biological Macromolecules, 102, 1045-1051. http://dx.doi. org/10.1016/j.ijbiomac.2017.04.084. PMid:28450244.

65. Kamoun, E. A., Kenawy, E.-R. S., Tamer, T. M., El-Meligy, M. A., \& Mohy Eldin, M. S. (2015). Poly (vinyl alcohol)-alginate physically crosslinked hydrogel membranes for wound dressing applications: characterization and bio-evaluation. Arabian Journal of Chemistry, 8(1), 38-47. http://dx.doi.org/10.1016/j. arabjc.2013.12.003.

66. Kenawy, E.-R., Kamoun, E. A., Mohy Eldin, M. S., \& ElMeligy, M. A. (2014). Physically crosslinked poly(vinyl alcohol)-hydroxyethyl starch blend hydrogel membranes: synthesis and characterization for biomedical applications.
Arabian Journal of Chemistry, 7(3), 372-380. http://dx.doi. org/10.1016/j.arabjc.2013.05.026.

67. Lopez, C. G., Rogers, S. E., Colby, R. H., Graham, P., \& Cabral, J. T. (2015). Structure of sodium carboxymethyl cellulose aqueous solutions: A SANS and rheology study. Journal of Polymer Science. Part B, Polymer Physics, 53(7), 492-501. http://dx.doi.org/10.1002/polb.23657. PMid:26709336.

68. Shi, C., Tao, F., \& Cui, Y. (2018). New starch ester/gelatin based films: developed and physicochemical characterization. International Journal of Biological Macromolecules, 109, 863-871. http://dx.doi.org/10.1016/j.ijbiomac.2017.11.073. PMid:29137995.

69. Pereira, R. F., Carvalho, A., Gil, M. H., Mendes, A., \& Bártolo, P. J. (2013). Influence of Aloe vera on water absorption and enzymatic in vitro degradation of alginate hydrogel films. Carbohydrate Polymers, 98(1), 311-320. http://dx.doi. org/10.1016/j.carbpol.2013.05.076. PMid:23987350.

70. Bhowmick, S., \& Koul, V. (2016). Assessment of PVA/silver nanocomposite hydrogel patch as antimicrobial dressing scaffold: synthesis, characterization and biological evaluation. Materials Science and Engineering C, 59, 109-119. http:// dx.doi.org/10.1016/j.msec.2015.10.003. PMid:26652355.

71. Porayath, C., Suresh, M. K., Biswas, R., Nair, B. G., Mishra, N., \& Pal, S. (2018). Autolysin mediated adherence of Staphylococcus aureus with fibronectin, gelatin and heparin. International Journal of Biological Macromolecules, 110, 179-184. http://dx.doi.org/10.1016/j.ijbiomac.2018.01.047. PMid:29398086.

72. Vijaya, K. K., \& Nishteswar, K. (2012). Wound healing activity of honey: a pilot study. Ayu: an International Quarterly Journal of Research in Ayurveda, 33(3), 374-377. http://dx.doi. org/10.4103/0974-8520.108827. PMid:23723644.

73. Miorin, P. L., Levy, N. C., Jr., Custodio, A. R., Bretz, W. A., $\&$ Marcucci, M. C. (2003). Antibacterial activity of honey and propolis from Apis mellifera and Tetragonisca angustula against Staphylococcus aureus. Journal of Applied Microbiology, 95(5), 913-920. http://dx.doi.org/10.1046/j.1365-2672.2003.02050.x. PMid:14633019.

74. Giusto, G., Beretta, G., Vercelli, C., Valle, E., Iussich, S., Borghi, R., Odetti, P., Monacelli, F., Tramuta, C., Grego, E., Nebbia, P., Robino, P., Odore, R., \& Gandini, M. (2018). Pectin-honey hydrogel: characterization, antimicrobial activity and biocompatibility. Bio-Medical Materials and Engineering, 29(3), 347-356. http://dx.doi.org/10.3233/BME-181730. PMid:29578463.

75. Zbuchea, A. (2014). Up to date use of honey for burns treatment. Annals of Burns and Fire Disasters, 27(1), 22-30. PMid:25249844. 